\title{
New Prayers and Invocations to Hathor among Unpublished Dipinti from the Thutmose III Temple at Deir el-Bahari
}

\author{
MirosŁaW BARWIK
}

\begin{abstract}
This paper presents a group of nine fragmentarily preserved dipinti from the Temple of Thuthmose III in Deir el-Bahari. The pieces belong to the corpus of dipinti discovered by the Polish Archaeological Mission at the beginning of the 1960s, the bulk of which was already published by the late Marek Marciniak.
\end{abstract}

Keywords: New Kingdom Egypt, Deir el-Bahari, Tuthmosis III temple, hieratic dipinti

Mirosław Barwik, Faculty of Archaeology, University of Warsaw, Warsaw; mbarwik@uw.edu.pl;

(iD) 0000-0002-1389-7457

The corpus of hieratic dipinti from the Thuthmose III temple at Deir el-Bahari may be enriched by dozens of unpublished fragments. Though Marek Marciniak included some of the fragmentarily preserved dipinti in his edition, ${ }^{1}$ most of the material of this kind was omitted by him, mainly due to the imperfect state of preservation of the pieces in question. ${ }^{2}$ The unpublished material provides new prosopographic data, but the bulk of the inscriptions is restricted to fragments of prayers and invocations. This is the case of the prayers to Hathor presented here, which were drawn up according to the well documented pattern. ${ }^{3}$

None of the presented fragments is recorded in the published catalogues of finds, as the fragments with hieratic dipinti were excluded with the aim of their being published separately by Marciniak. ${ }^{4}$

Nothing certain can be said about the precise dating of the inscriptions presented here, except the mere fact that they were written in Ramesside hieratic. The wab-priest Hori mentioned in the penultimate inscription (DeB 152) cannot be related convincingly to any of the persons of that name, known from the Theban sources.

\footnotetext{
1 Marciniak 1974.

2 Cf. Marciniak 1974: 15, 18, n. 24.

3 Cf. Marciniak 1968; 1973; 1974: 20ff.; Sabek 2016: $23 \mathrm{ff}$.

${ }^{4}$ Cf. Lipińska 1968: 205.
} 

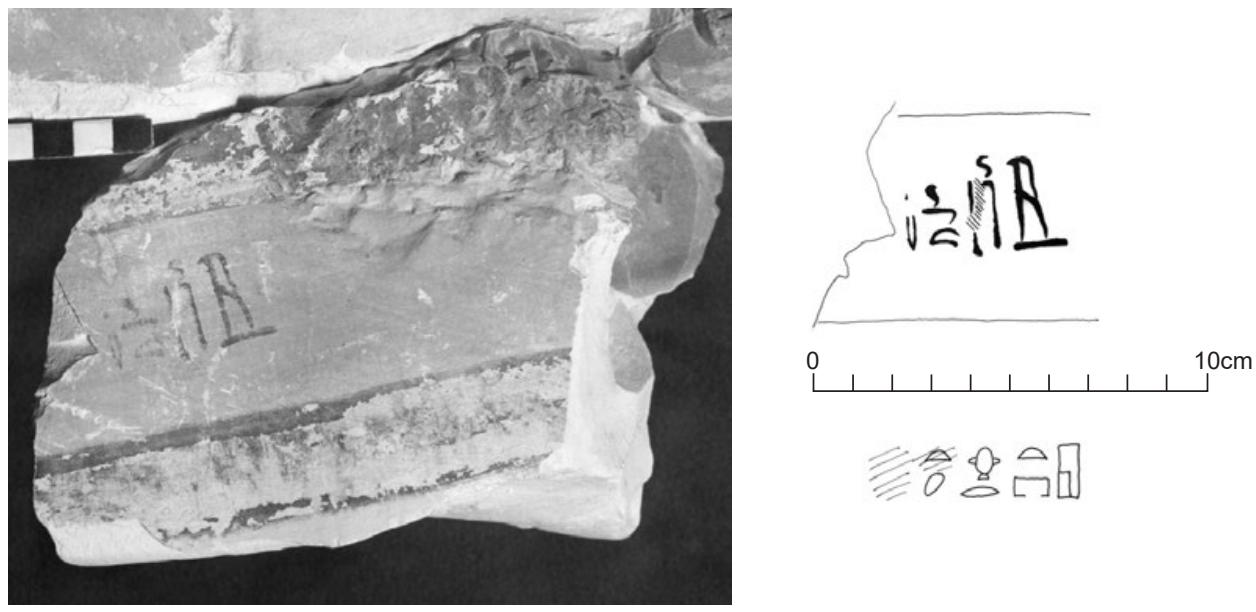

a

b

1a. Dipinto DeB 145 on the limestone fragment inv. no. F. 5767; b. facsimile and transcription of the hieratic text (Phot. S. Sadowski; drawing: M. Barwik).

\section{DIPINTO DeB $145^{5}$ (Fig. 1a-b)}

Written in black ink on a limestone fragment within the upper (red) band of a dado ornament (inv. no. F. 5767).

Transliteration and commentary:

$H w t-H r(w)[\ldots ?]^{a)}$

a) There is no certainty in fact that the text was continued, as there are no traces of the following sign. It is possible that a typical extension of the type $n b . t \underline{D}$ sr.t should follow the preserved signs. In any case the text seems to be just a simple invocation to Hathor.

Translation:

Hathor [...?].

\section{DIPINTO DeB 146 (Fig. 2a-b)}

Written in black ink on a limestone fragment within the lower (yellow) band of a dado ornament (inv. no. F. 8046).

Transliteration and commentary:

$\left.[\ldots H w t-H r(w)]^{\text {a) }} n b(. t) \underline{D} s r . t^{b}\right)$ ir $n f r[\ldots]$

a) Fragment of the determinative of the goddess' name (I 12 of Gardiner's sign-list) preserved.

${ }_{5}^{5}$ The numbers given here follow those of the Marciniak's edition, and two dipinti published previously by the present author (Barwik 2009). 

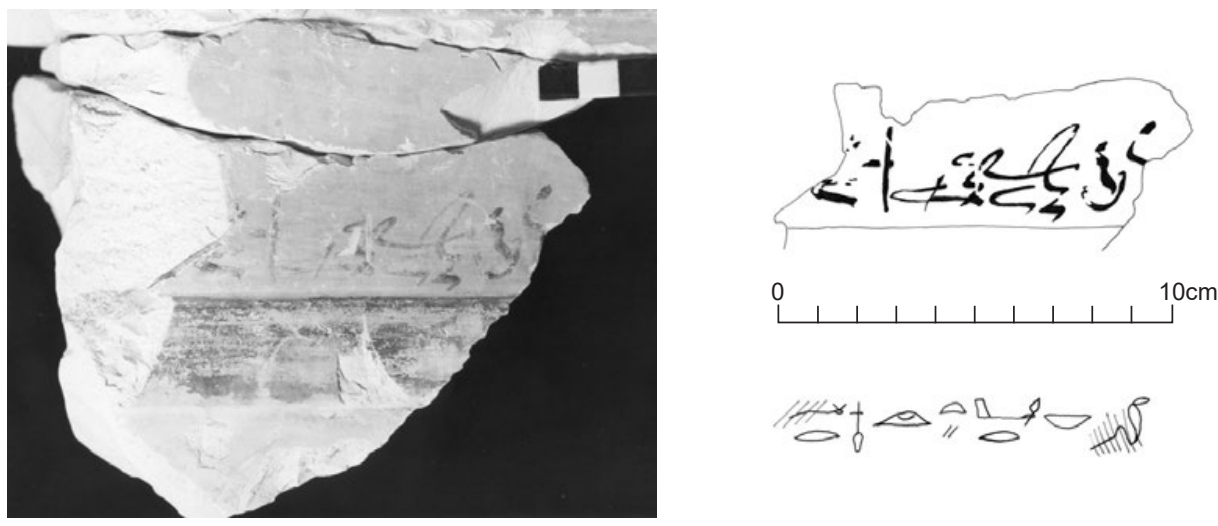

a

b

2a. Dipinto DeB 146 on the limestone fragment inv. no. F. 8046; b. facsimile and transcription of the hieratic text (Phot. S. Sadowski; drawing: M. Barwik).

b) Writing unattested elsewhere, possibly influenced by the form of the type Dsr.ty.t of ostracon BN, 8 (parallel to Dsr.t, cf. Fischer-Elfert 1983: 31= Gardiner 1911: 4, 11; Lesko 2004: 275); compare also Dsr.t(y).t in the vignette of the Book of the Dead chapter 124 on the papyrus of Merit (cf. Naville 1886: 132 (P.j)).

Translation:

[... Hathor] Lady of Djeseret; do good [...].

\section{DIPINTO DeB 147 (Fig. 3a-b)}

Written in black ink on a sandstone fragment of a column (inv. no. F. 7698).

Transliteration:

(1) ir $n f r H w t-H r(w)[\ldots](2) n f[r \ldots]$

Translation:

(1) Do good, Hathor [...] (2) goo[d ...].

\section{DIPINTO DeB 148 (Fig. 4a-b)}

Written in black ink on a sandstone fragment of a column (inv. no. F. 6348).

Transliteration and commentary:

$[\ldots H w t-H r(w)]^{\mathrm{a})} n b . t \underline{D} \operatorname{sr} . t$ ir $[n f r \ldots]$

a) Fragment of the determinative of the goddess' name (I 12 of Gardiner's sign-list) preserved. 

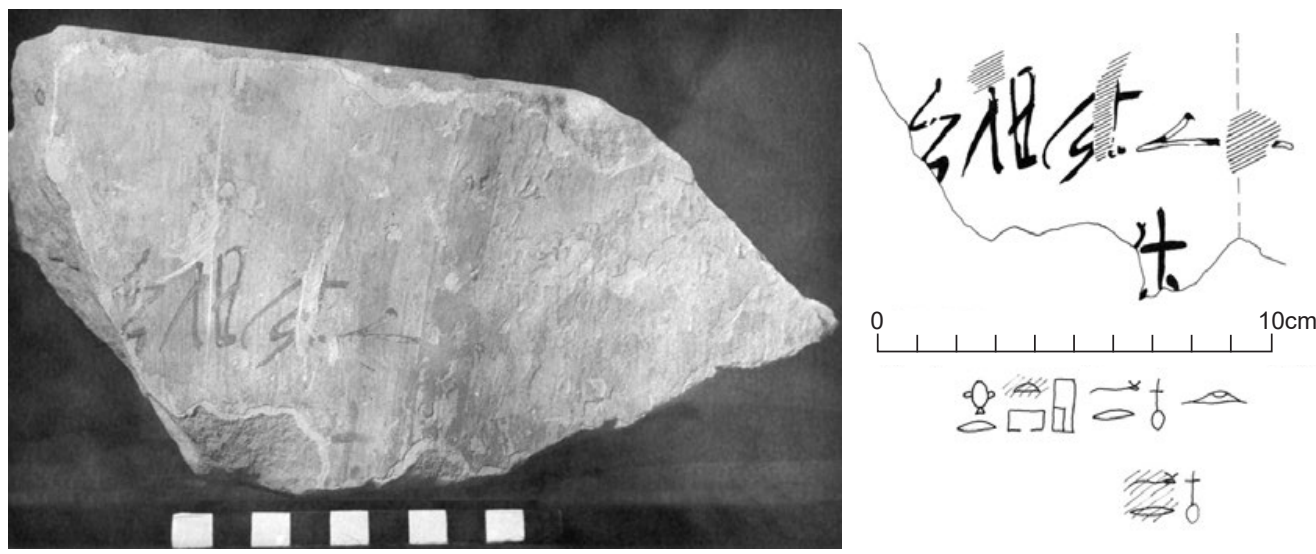

b

3a. Dipinto DeB 147 on the sandstone fragment inv. no. F. 7698; b. facsimile and transcription of the hieratic text (Phot. S. Sadowski; drawing: M. Barwik).
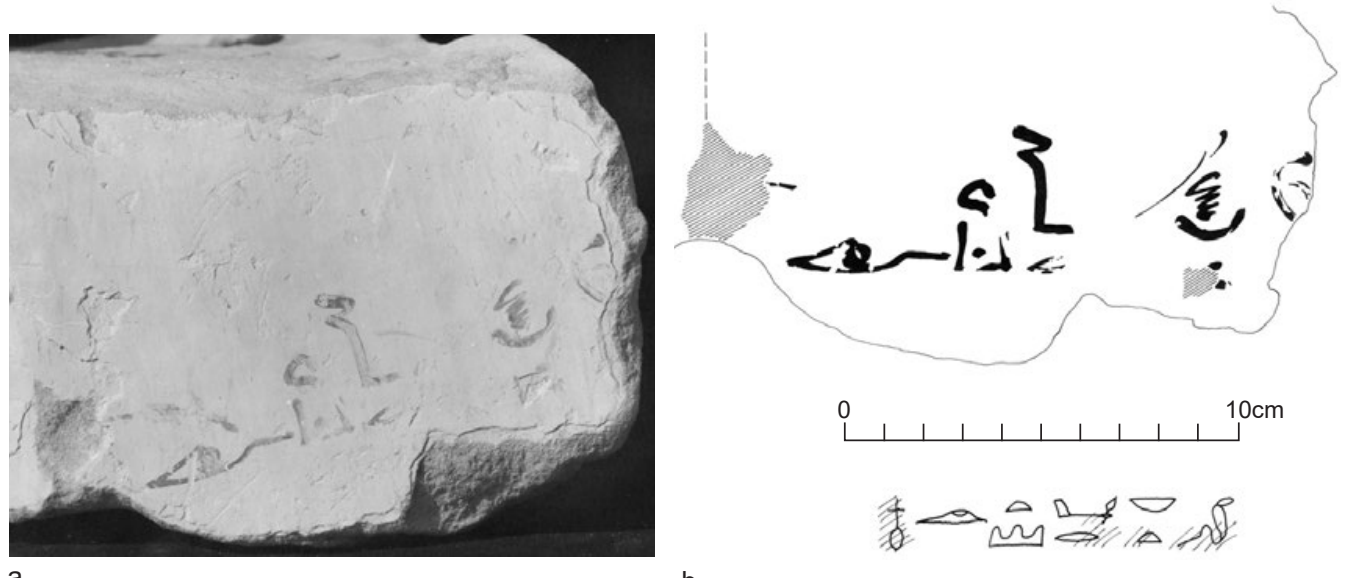

a

4a. Dipinto DeB 148 on the sandstone fragment inv. no. F. 6348; b. facsimile and transcription of the hieratic text (Phot. S. Sadowski; drawing: M. Barwik).

Translation:

[... Hathor] Lady of Djeseret; do [good ....

\section{DIPINTO DeB 149 (Fig. 5a-b)}

Written in black ink on a sandstone fragment of a column (inv. no. F. 2364+2365). ${ }^{6}$

Transliteration and commentary:

$[\ldots H w t-H r(w)]^{a)} n b . t t 3 \underline{d} s r$ ir $[n f r \ldots]$

${ }^{6}$ The fragments joined together by the present author. 


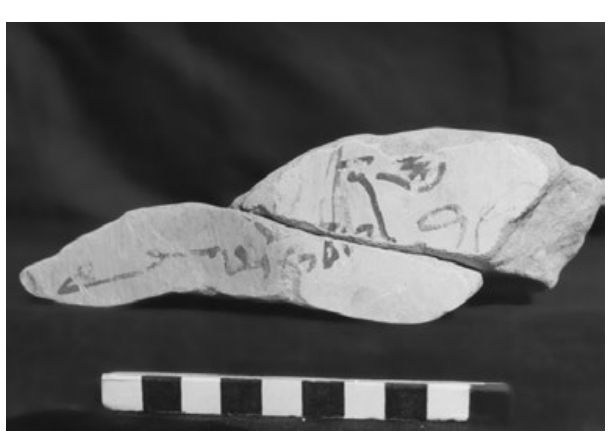

a
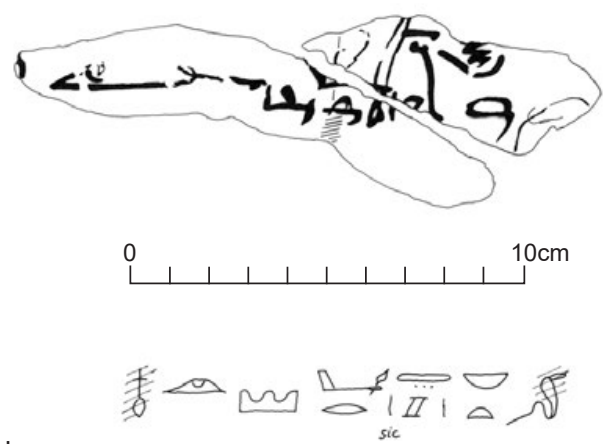

5a. Dipinto DeB 149 on the sandstone fragment inv. no. F. 2364+2365; b. facsimile and transcription of the hieratic text (Phot. S. Sadowski; drawing: M. Barwik).

a) Fragment of the determinative of the goddess's name (I 12 of Gardiner's sign-list) preserved.

Translation:

[... Hathor] Lady of the Sacred Land (i.e. necropolis); ${ }^{7}$ do $[\operatorname{good} . .$.$] .$

\section{DIPINTO DeB 150 (Fig. 6a-b)}

Written in black ink on a sandstone fragment of a column (inv. no. F. 7231).

Transliteration and commentary:

(1) $\operatorname{ir} n f r[\ldots]$ (2) $H w t-H r(w)[n b . t \ldots]$ (3) $[\ldots]^{\text {a) }}$ (4) $[\ldots]^{\mathrm{b})}$

a) Traces only.

b) Traces only.

Translation:

(1) Do good [...] (2) Hathor [Lady ...] (3) [...] (4) [...].

\section{DIPINTO DeB 151 (Fig. 7a-b)}

Written in black ink on a sandstone fragment of a column (inv. no. F. 8331).

Transliteration and commentary:

(1) $\left[\ldots n b . t \underline{D} s r . t^{\mathrm{a})}\right] \operatorname{ir} n f r(2)[\ldots]$... $^{\mathrm{b})}$ mh h h.t.f h.bs $[\ldots]^{\mathrm{c})}$

${ }^{7}$ For the epithet $n b . t t 3 \underline{d s}$ in relation to Hathor, see dipinto DeB 60: Marciniak 1974: 111-112, Pl. 47A.3 with corrections made by Sabek 2016: 326 (no. 98); compare also dipinto DeB 37 ( $n t 3 \underline{d} s r$ ): Marciniak 1974: 93-94, Pls 32-32A with corrections suggested by Sabek 2016: 255-256 (no. 62). 


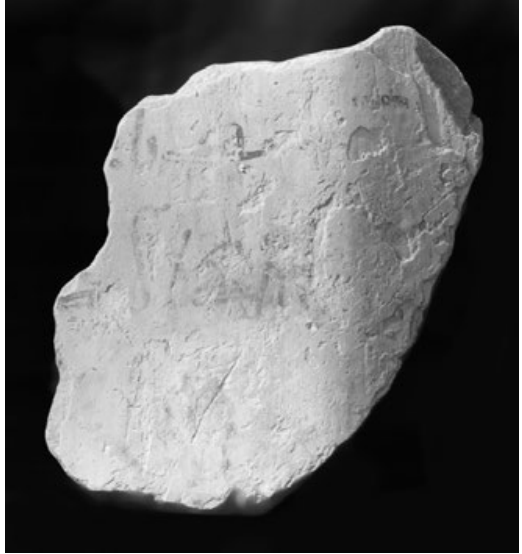

a

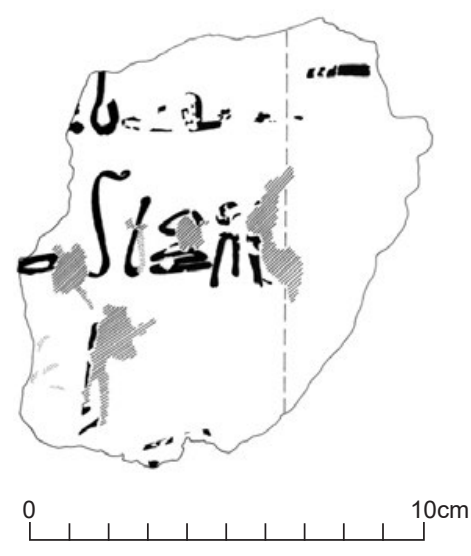

b

6a. Dipinto DeB 150 on the sandstone fragment inv. no. F. 7231; b. facsimile and transcription of the hieratic text (Phot. S. Sadowski; drawing: M. Barwik).

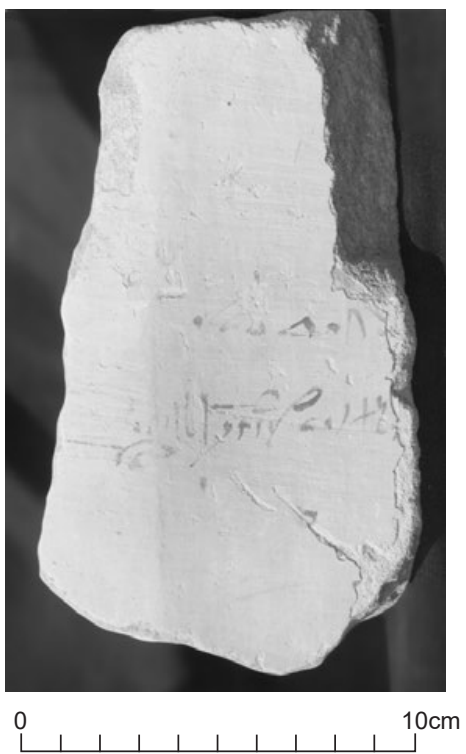

a

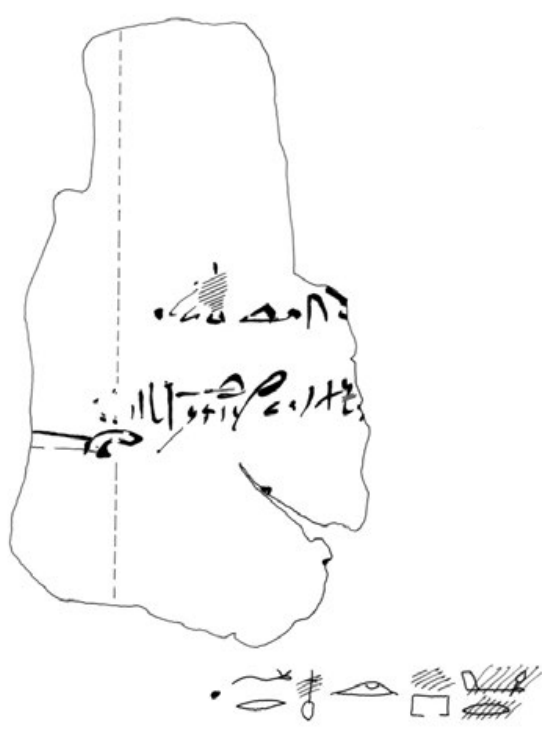

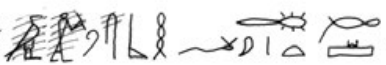

7a. Dipinto DeB151 on the sandstone fragment inv. no. F. 8331; b. facsimile and transcription of the hieratic text (Phot. S. Sadowski; drawing: M. Barwik).

a) Only traces of the toponym preserved. As regards the determinative used here, compare graffito DeB 28: Marciniak 1974: 85, Pls 25.2-25A.2.

b) Reading doubtful; perhaps the last signs of $m 3{ }^{\mathrm{C}} . t$ should be expected here (cf. DeB 38 and 53) but it is highly doubtful; the prothetic $i$ of the imperative i.mh seems to be excluded as well. 
a
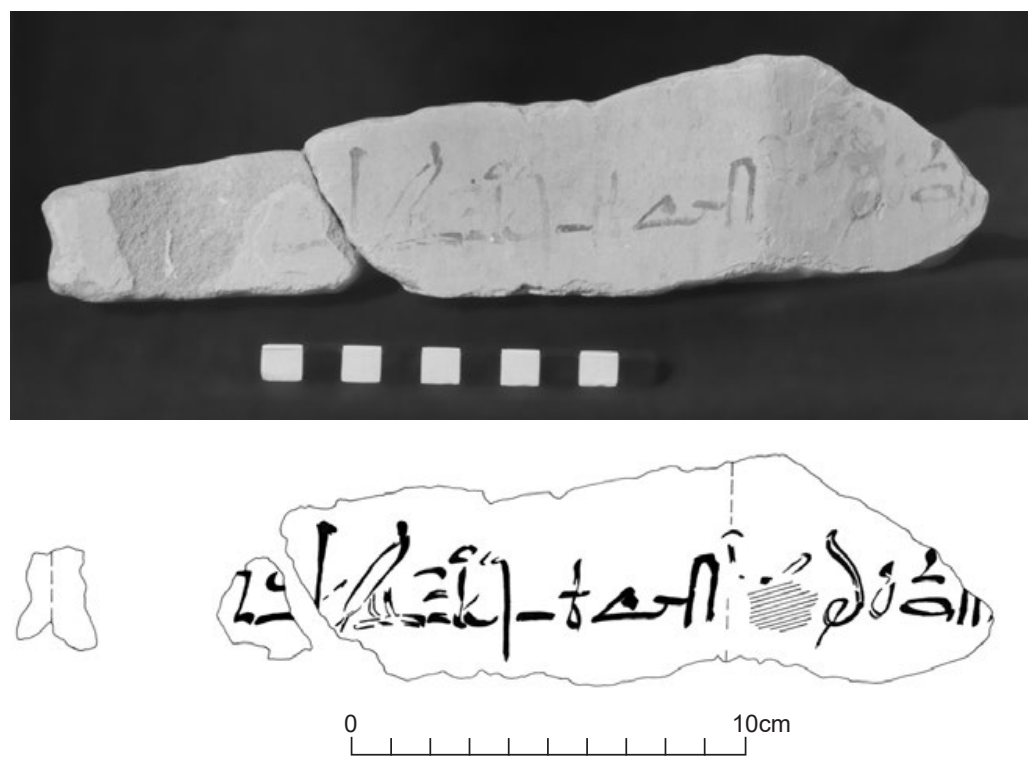

b

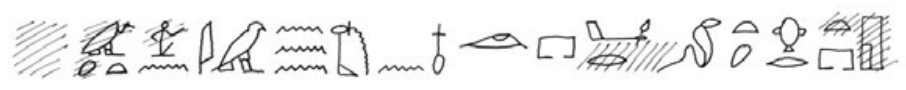

8a. Dipinto DeB 152 on the sandstone fragment inv. no. F. 7566 + fragment without number; b. facsimile and transcription of the hieratic text (Phot. S. Sadowski; drawing: M. Barwik).

c) Signs of the last word (i3.t.f) faded; the end of the line underlined by a rather obscure sign devoid of any meaning.

Translation:

(1) [... Lady of Djeseret]; do good (2) [... ... fill his stomach and clothe [his back].

\section{DIPINTO DeB 152 (Fig. 8a-b)}

Written in black ink on a sandstone fragment of a column (inv. no. F. $7566+$ fragment without number). ${ }^{8}$

Transliteration and commentary:

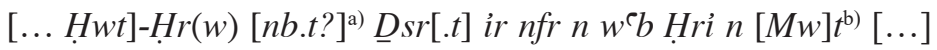

a) There is no place for $n b(. t)$ - either it was placed in the lacuna or simply omitted?

b) As regards the hieratic form of the ligature for Mwt, see: Möller 1927: 17 (194); Marciniak 1974: 263.

\footnotetext{
${ }^{8}$ The fragments joined together by the present author.
} 


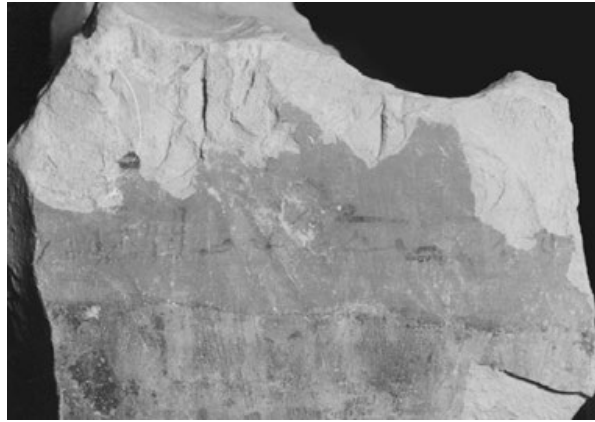

a

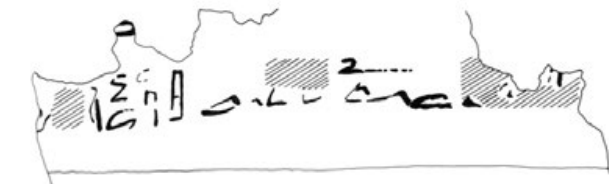

$10 \mathrm{~cm}$

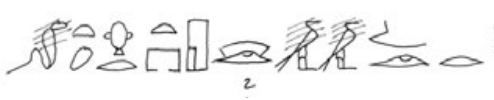

b

9a. Dipinto DeB 153 on the limestone fragment inv. no. F. 7927; b. facsimile and transcription of the hieratic text (Phot. S. Sadowski; drawing: M. Barwik).

Translation:

[... Hat]hor [Lady] of Djeser[et]; do good to the wab-priest of [Mu]t, Hori [...].

\section{DIPINTO DeB 153 (Fig. 9a-b)}

Written in black ink on the upper (red) band of a dado ornament; limestone fragment (inv. no. F. 7927).

Transliteration and commentary:

$(1+\mathrm{x})[\ldots]^{\mathrm{a})}(2+\mathrm{x})[\ldots]^{\mathrm{b})} \mathrm{r} m 33 \operatorname{Hwt}-\mathrm{Hr}(w)[\ldots]$

a) Traces of one sign preserved. After all, there is no certainty that this is a remnant of a separate upper line of the inscription.

b) Traces only.

Translation:

$(1+\mathrm{x})[\ldots](2+\mathrm{x})[\ldots]$ to see Hathor $[\ldots]$

Nothing certain can be said about the course of the feasts of Hathor celebrated at Deir el-Bahari. The sequence of scenes depicted in the Chapel of Hathor in the Hatshepsut temple gives only a general impression of the events relating to these festivities. Significantly, the date of the feast was given by some of the Deir el-Bahari graffiti, i.e. DeB 17, 63, 114, and possibly also 58 and $7 .{ }^{9}$

It is open to debate whether the 'seeing Hathor', mentioned in graffito DeB 153, relates to these festivities, and seeing the statue of Hathor in particular. ${ }^{10}$ It cannot be excluded that these cultic performances took place during the Beautiful Feast of the Valley, as in the

9 Cf. Dolińska 2007: 77, n. 39; Sabek 2016: 95; for the date of the Hathor feast, see also: Schott 1950: 59.

${ }_{10}$ As regards the idea of seeing a god, see: Sabek 2016: 86; cf. also: Van der Plas 1989; Moret 1902: 55 (11), 113 (28); Guglielmi, Buroh 1997: 125 (a). 
case of the events commemorated in graffito DeB $31 .{ }^{11}$ At least two more dipinti written in the Deir el-Bahari Temple of Thutmose III conspicuously mention 'seeing Hathor' - these are dipinti DeB 114 and 129 of Marciniak. ${ }^{12}$ The former relates to 'coming to see $(m 33)^{13}$ Hathor' on the first day of the fourth month of akhet, i.e. on the date of the Hathor feast. Dipinto DeB 129 was left in the name of three priests of the three great temples of the Theban west side, who visited Deir el-Bahari 'to see (ptr) Hathor, mistress of Djeseret'. Graffito DeB 39 (lines 3-4) (4) $^{14}$ entions the visit of a pious lady coming to see the statue of Meretseger (i.ly m33.t, 'who has come (to) see you'), no doubt during her festival. ${ }^{15}$ The formulae in question find a parallel in those attested in graffito DeB 17 (lines 5 and 6: m33 Imn, 'seeing Amun'), ${ }^{16}$ and possibly also in DeB 72 (line 4: $r$ di.t [m33].i Imn), ${ }^{17}$ being presumably references to 'seeing' the god's statue during the Beautiful Feast of the Valley. ${ }^{18}$ The text of graffito DeB 1 (lines 33-34) states unequivocally that it was a festival procession which gave the opportunity to look at the statue of the goddess: $r w d n$ $n H w t-H r(w)[r]{ }^{\ulcorner} m 3^{3}{ }^{\top} m h^{\ulcorner} w . s n f r$, 'to offer to Hathor, and [to] ${ }^{\Gamma} \mathrm{see}^{\top}$ (her) in her beautiful processional appearance'. ${ }^{19}$

\section{Acknowledgements}

I am grateful to Paul Barford for revising my English.

\section{References}

Barwik, M. 2009: Two pilgrims from Armant at Deir el-Bahari, SAK 38, 45-52

Dolińska, M. 2007: Temples at Deir el-Bahari in the New Kingdom, [in:] Haring, B., Klug, A. (Eds), 6. Ägyptologische Tempeltagung. Funktion und Gebrauch altägyptischer Tempelräume. Leiden, 4-7. September 2002, KSG 3(1), Wiesbaden, 71-87

11 Marciniak 1974: 87-88, Pls 28-28A = 1971: 54-56.

12 Marciniak 1974: 144, 151-152, Pls 77A.1, 85-85A; see also: Sabek 2016: 140-141 (no. 3), 357 (no. 122).

${ }^{13}$ Sabek (2016: 357) is certainly wrong assuming that the verb $n w$ should be read here, as the new facsimile clearly shows: infitzo.

14 Marciniak 1974: 95-96, Pls 34-34A; cf. also Sadek 1984b: 66; Sabek 2016: 200-201 (no. 35).

15 Cf. Sadek 1987: 173; Sabek 2016: 97, 200-201.

16 Marciniak 1974: 76, P1. 17; Marciniak's reading differs substantially in two places from the more plausible interpretation in Sabek 2016: 317 (no. 91), and 318 (note Z.(5)).

17 Marciniak 1974: 121-122, Pls 57.1-57A.1 with corrections proposed by Sabek 2016: 307 (no. 86). It is also worth noting that Marciniak's rendering of dipinto DeB 71 line $\mathrm{x}+1$ : $r$ m33, 'to see' (Marciniak 1974: 121, Pls 56-56A; see also: Sadek 1984b: 74), differs substantially from that of Sabek 2016: 336-337 (no. 105).

18 Seee Sabek's restoration of DeB 72 (line 4): ( $m$ ) in [.t n]fr.t, 'beim schö[nen Ta]lfest' (Sabek 2016: 97, 307). As regards 'seeing' Amun during his festivals, see: Schott 1934: 73; 1953: 35, 108 (67, 69), 109 (73, 74); see also Theban graffito 1012a: Spiegelberg 1921: 84-85, Pl. 114; KRI V: 542 (A175). For the relationship of Hathor to the Beautiful Feast of the Valley, see: Sabek 2016: 14-15.

19 Reading according to the new rendering of the text given by Sabek 2016: 262 (no. 66), 267 (note Z.(34)), differing from that proposed by Marciniak 1974: 56 (compare Pls 1-1A); otherwise Sadek 1984a: 71. For the meaning of $h^{\complement} y / h^{\complement} w$, see e.g.: Lesko 2002: 352. 
Fischer-Elfert, H.-W. 1983: Die satirische Streitschrift des Papyrus Anastasi I, KäT 7, Wiesbaden

Gardiner, A.H. 1911: Egyptian Hieratic Texts, Series I: Literary Texts of the New Kingdom. Part I: The Papyrus Anastasi I and the Papyrus Koller, together with the Parallel Texts, Leipzig

Guglielmi, W., Buroh, K. 1997: Die Eingangssprüche des Taglichen Tempelrituals nach Papyrus Berlin 3055 (I,1-VI,3), [in:] Dijk, J. van (Ed.), Essays on Ancient Egypt in Honour of Herman Te Velde, Egyptological Memoirs 1, Gröningen, 101-166

Lesko, L.H. 2002: A Dictionary of Late Egyptian I, Providence

Lesko, L.H. 2004: A Dictionary of Late Egyptian II, Providence

Lipińska, J. 1968: List of Objects Found at Deir el-Bahari in the Temple of Tuthmosis III, ASAE LX, 205-212

Marciniak, M. 1968: Quelques remarques sur la formule ir nfr, ir nfr, EtudTrav II, 25-31

Marciniak, M. 1971: Encore sur la Belle Fête de la Vallée, EtudTrav V, 53-64

Marciniak, M. 1973: Une formule empruntée à la sagesse de Ptaḥhotep, BIFAO LXXIII, $109-112$

Marciniak, M. 1974: Les inscriptions hiératiques du Temple de Thoutmosis III, Deir el-Bahari I, Varsovie

Moret, A. 1902: Le rituel du culte divin journalier en Égypte d'après les papyrus de Berlin et les textes du temple de Séti I ${ }^{\text {er }}$, à Abydos, Paris

Möller, G. 1927: Hieratische Paläographie, vol. II, Leipzig

Naville, E. 1886: Das Aegyptische Todtenbuch der XVIII. bis XX. Dynastie, vol. I, Berlin

Plas, D. van der 1989: "Voir" Dieu. Quelques observations au sujet de la fonction des sens dans le culte et la dévotion de l'Égypte ancienne, BSFE 115, 4-35

Sabek, Y. 2016: Die hieratischen Besucher-Graffiti $\underline{d} s r-3 h . t$ in Deir el-Bahari, IBAES 18, London

Sadek, A.I. 1984a: An Attempt to Translate the Corpus of the Deir el-Bahari Hieratic Inscriptions, GöttMisz 71, 67-91

Sadek, A.I. 1984b: An Attempt to Translate the Corpus of the Deir el-Bahari Hieratic Inscriptions, GöttMisz 72, 65-86

Sadek, A.I. 1987: Popular Religion in Egypt during the New Kingdom, Ḧ̈B 27, Hildesheim

Schott, S. 1934: The Feasts of Thebes, [in:] Nelson, H.H., Hölscher, U., Schott, S., Work in Western Thebes 1931-33, OIC 18, Chicago, 63-90

Schott, S. 1950: Altägyptische Festdaten, $A G S K$ 10, Wiesbaden

Schott, S. 1953: Das schöne Fest vom Wüstentale. Festbräuche einer Totenstadt, $A G S K$ 11, Wiesbaden

Spiegelberg, W. 1921: Ägyptische und andere Graffiti (Inschriften und Zeichnungen) aus der thebanischen Nekropolis, Heidelberg 


\section{ÉTUDES et TRAVAUX XXXIII / 2020}
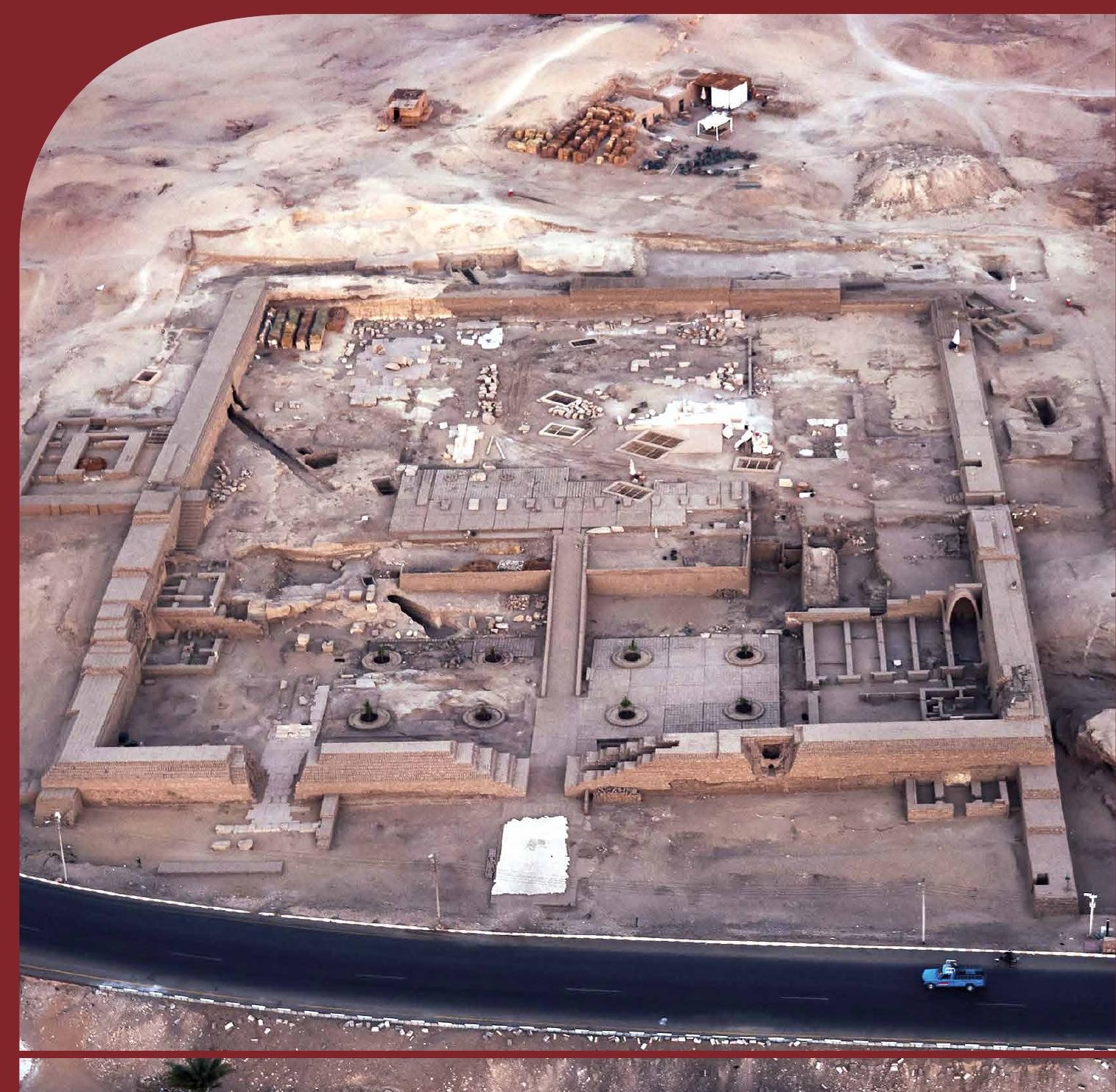

BOPIKSiO Institut des Cultures Mediterranéennes et Orientales IST PAN de l'Académie Polonáise des Sciences 


\title{
COMITÉ DE RÉDACTION SCIENTIFIQUE
}

Maciej Makowski - rédacteur en chef Jadwiga Iwaszczuk - rédacteur

Agnieszka Ryś - secrétaire de la rédaction

Ewa Laskowska-Kusztal - rédacteur thématique du volume

CONSEIL SCIENTIFIQUE DU JOURNAL

Michał Kobusiewicz (IAE PAN, Warszawa)

Ewa Laskowska-Kusztal (IMOC PAS, Warszawa)

Demetrios Michaelides (University of Cyprus, Nicosia)

Jean-Charles Moretti (IRAA-MOM, Université de Lyon 2/CNRS)

Dietrich Raue (Ägyptisches Museum der Universität Leipzig)

Paul Reynolds (ICREA, España)

Derek Welsby (British Museum, London)

COMITÉ SCIENTIFIQUE DE LECTURE

la liste des membres du comité est accessible en ligne sur

http://www.etudesettravaux.iksiopan.pl

\author{
RÉDACTION TECHNIQUE \\ Jadwiga Iwaszczuk \\ Maciej Makowski
}

REVUE DES TEXTES EN ANGLAIS

Jo Harper 
ÉTUDES et TRAVAUX XXXIII 
INSTYTUT KULTUR ŚRÓDZIEMNOMORSKICH I ORIENTALNYCH POLSKIEJ AKADEMII NAUK

\title{
STUDIA i PRACE
}

XXXIII

\author{
ROIKŚSiO \\ ESOPAN \\ WARSZAWA \\ 2020
}


INSTITUT DES CULTURES MÉDITERRANÉENNES ET ORIENTALES DE L'ACADÉMIE POLONAISE DES SCIENCES

\section{ÉTUDES et TRAVAUX}

XXXIII

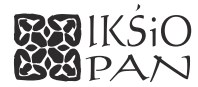

VARSOVIE

2020 
Publication scientifique financée dans le cadre du programme du Ministre de la Science et de l'Éducation Supérieure

« Programme National de Développement de l'Humanistique » pour les années 2016-2021 (projet no 3bH 150099 83)

\title{
UARODOWY PROGRAM ROZWOJU HUMANISTYKI
}

\author{
Copyright (C) \\ Instytut Kultur Śródziemnomorskich i Orientalnych PAN \\ et les Auteurs \\ Warszawa 2020
}
ISSN 2084-6762
(jusqu'en 2011 : 0079-3566)
e-ISSN 2449-9579
Version première en papier, imprimée en Pologne - 150 copies
Version électronique accessible sur
http://www.etudesettravaux.iksiopan.pl

Édition: Polskie Towarzystwo Historyczne et Wydawnictwo Neriton, Warszawa

Conception générale de la couverture : J. Iwaszczuk

Photographie de couverture : J. Pablo Moreira (C) Thutmosis III Temple Project

(Henket-ankh, le temple des Millions d'Années de Thoutmosis III, Louxor) 


\section{Table des matières}

Editorial (par Ewa Laskowska-Kusztal) ................................................................... 7

MirosŁaW BARWIK

Two Portraits of Senenmut in the Hatshepsut Temple at Deir el-Bahari

MirosŁaW BARWIK

New Prayers and Invocations to Hathor among Unpublished Dipinti

from the Thutmose III Temple at Deir el-Bahari

LiNDA CHAPON

The Decoration of the Columns and Pillars from the Henket-ankh of Thutmose III

(Western Thebes)

Abraham I. Fernández Pichel

Quelques blocs ptolémaïques inédits de la cour du IX pylône du domaine

d'Amon à Karnak

Amgad Joseph

The Stela of Haremwia, Chief of the Provisioning Sector of the Temple Workshop

(CG 34079 / JE 22011)

EWA JÓZEFOWICZ

Ramesside Inscriptions and Preparatory Sketches in the Western Wall of Portico

of Obelisks of Hatshepsut's Temple at Deir el-Bahari

Miral LASHIEN

Donkeys in the Old and Middle Kingdoms According to the Representations

and Livestock Counts from Private Tombs

AleKsandra Pawlikowska-Gwiazda

Christian Secondary Epigraphy in the Temple of Hatshepsut. Some New Remarks

KRZYSZTOF RADTKE

Square Grids in the Tomb of Akhethotep - Questions and Doubts

Myriam Seco Álvarez, JaVier Martínez Babón

The Temple of Millions of Years of the Pharaoh Thutmose III (Luxor). An Update on the Research 